Journal of Aafiyah Health Research (JAHR)

P-ISSN: 2722-4929 \& E-ISSN: 2722-4945

Published by Postgraduate Program in Public health, Muslim University of Indonesia

\title{
PENGARUH FASILITAS KESEHATAN DAN MOTIVASI KERJA TERHADAP KEPUASAN PASIEN MELALUI KUALITAS PELAYANAN PADA UNIT RAWAT INAP DI RSUD HAJI MAKASSAR PROVINSI SULAWESI SELATAN
}

\author{
*Aznira Nurul Hidayah ${ }^{1}$,Nurmiati Muchlis ${ }^{1}$, Rasyidin Abdullah ${ }^{1}$ \\ ${ }^{1}$ Program Pascasarjana Kesehatan Masyarakat, Universitas Muslim Indonesia
}

*Email: azniranh@gmail.com

\begin{abstract}
ABSTRAK
Latar belakang: Pengukuran kepuasan pasien merupakan elemen penting dalam menyediakan pelayanan yang lebih baik, lebih efisien dan lebih efektif. Penelitian ini bertujuan menganalisis pengaruh fasilitas kesehatan dan motivasi kerja terhadap kepuasan pasien melalui kualitas pelayanan pada unit rawat inap di RSUD Haji Makassar Provinsi Sulawesi Selatan. Metode: Rancangan penelitian yang dipakai dalam penelitian ini adalah survei analitik dengan pendekatan Cross Sectional Study. Pengambilan sampel dilakukan dengan metode total sampling dengan jumlah sampel sebanyak 68 orang. Metode analisis data menggunakan analisis statistik perhitungan dengan menggunakan program SPSS dengan menggunakan analisis jalur (path analysis). Hasil: Hasil penelitian menunjukkan dari hasil uji sobel terdapat pengaruh signifikan dan positif variabel fasilitas kesehatan sebesar t hitung 3,984>1,987 dan motivasi kerja t hitung sebesar 3,011>1,987 terhadap kepuasan pasien melalui kualitas pelayanan, terdapat pengaruh signifikan variabel fasilitas kesehatan $0,000<0,005$ terhadap kepuasan, tidak ada pengaruh yang signifikan variabel motivasi kerja 0,155 >0,000 terhadap kepuasan pasien, terdapat pengaruh signifikan variabel fasilitas kesehatan $0,000<0,005$ dan variabel motivasi kerja $0,001<0,005$ terhadap kualitas pelayanan, dan terdapat pengaruh signifikan variabel kualitas pelayanan $0,000<0,005$ terhadap kepuasan pasien. Kesimpulan : Kesimpulan dari penelitian menunjukkan bahwa terdapat pengaruh fasilitas kesehatan dan motivasi kerja terhadap kepuasan pasien melalui kualitas pelayanan di RSUD Haji Makassar Provinsi Sulawesi Selatan. Sehingga disarankan kepada pihak rumah sakit untuk mempertahankan kualitas pelayanannya.
\end{abstract}

Kata kunci : kepuasan, fasilitas kesehatan, motivasi, dan kualitas pelayanan 


\begin{abstract}
Background: Measurement of customer satisfaction is an important element in providing better, efficient and more effective service. This study aims to determine the effect of health facilities and work motivation on patient satisfaction through service quality in inpatient units at Haji Makassar Hospital, South Sulawesi Province. Method: The research design used in this study was an analytic survey with a Cross Sectional Study approach. Sampling was done by total sampling method with a total sample of 68 people. Methods of data analysis using statistical analysis calculations using the SPSS program using path analysis. Results: The results showed that from the Sobel test there was a significant and positive effect of the health facility variable at $t$ count 3.984>1.987 and work motivation $t$ count of 3.011> 1.987 on patient satisfaction through service quality, there was a significant effect of the health facility variable $0.000<0.005$ on satisfaction, no there is a significant effect of work motivation variable $0.155>$ 0.000 on patient satisfaction, there is a significant influence of the health facility variable 0.000 $<0.005$ and the work motivation variable $0.001<0.005$ on service quality, and there is a significant effect of the service quality variable $0.000<0.005$ on patient satisfaction.Conclusion: The conclusion of the study shows that there is an effect of health facilities and work motivation on patient satisfaction through the quality of service at Haji Makassar Hospital, South Sulawesi Province. So it is suggested to the hospital to maintain the quality of its service.
\end{abstract}

Keywords: satisfaction, health facilities, motivation and quality service.

\section{LATAR BELAKANG}

Pembangunan kesehatan merupakan salah satu upaya nasional pada semua bidang kehidupan yang hakekatnya diupayakan oleh semua komponen bangsa untuk mewujudkan kesehatan masyarakat yang setinggi-tingginya. Pembangunan dalam bidang kesehatan diharapkan dapat mewujudkan kualitas hidup manusia Indonesia yang tinggi, maju, dan sejahtera, serta bangsa yang memiliki daya saing. Keberhasilan pembangunan kesehatan kelak akan mencakup faktor kemudahan akses kesehatan serta peningkatan mutu pelayanan kesehatan yang terus menerus. Akses layanan kesehatan ditunjukkan dengan adanya peningkatan jumlah, jaringan dan kualitas fasilitas kesehatan. Sejalan dengan usaha peningkatan kualitas dan cakupan layanan kesehatan bagi masyarakat, sejumlah penyedia fasilitas kesehatan pun ditingkatkan. (1)

Saat ini kita berada di era global yang begitu ketat dalam pembangunan maupun persaingan yang ada di sekitar kita.

Tidak hanya terjadi dalam dunia bisnis, melainkan persaingan seperti ini juga terjadi pada setiap instansi jasa kesehatan, dimana mereka berlomba untuk memberikan fasiilitas serta pelayanan kesehatan yang terbaik bagi instansi maupun masyarakat yang memakai jasa atau pelayanan termasuk di bidang kesehatan. Adanya persaingan ini menjadikan pihak rumah sakit lebih berinovatif serta berbondong-bondong untuk menyediakan fasilitas kesehatan yang canggih dengan pelayanan yang terbaik guna membuat pasien memilih untuk melakukan pengobatan di rumah sakit mereka. (2)

Adanya konsep yang saat ini terjadi yaitu "customer oriented" yaitu sebuah konsep yang berorientasi pada pemenuhan kebutuhan konsumen, sehingga pihak rumah sakit dituntut untuk memberikan pelayanan yang terbaik guna memberikan rasa puas pada pasien. Sesuai dengan standar kepuasan pasien di pelayanan kesehatan yang ditetapkan secara nasional oleh Departemen Kesehatan. Berdasarkan 
Peraturan Kementerian Kesehatan Republik Indonesia Tahun 2016 Tentang Standar Pelayanan Minimal untuk kepuasan pasien yaitu diatas $95 \%$. Sehingga bila ditemukan pelayanan kesehatan dengan tingkat kepuasan pasien berada dibawah 95\%, maka dianggap pelayanan kesehatan yang diberikan tidak memenuhi standar minimal atau tidak berkualitas. (3)

Kepuasan pasien memiliki hubungan yang erat dengan kualitas. Kualitas memberikan suatu dorongan kepada pasien untuk menjalin ikatan hubungan yang kuat dengan rumah sakit.

Sebuah rumah sakit tentunya memiliki penyelenggaraan pelayanan kesehatan dengan konsep yang sangat kompleks. Konsep ini didasarkan pada sebuah interaksi antar berbagai jenis tenaga kesehatan terhadap ilmu pengetahuan, teknologi kedokteran serta kesehatan itu sendiri. Konsep yang kompleks ini, tentunya akan sangat berpengaruh terhadap kualitas pelayanan kesehatan yang nantinya akan berdampak terhadap kepuasan pasien dalam melakukan dan menerima layanan kesehatan di suatu rumah sakit.

Adanya persepsi terhadap kualitas pelayanan menjadi sebuah penilaian secara menyeluruh atas keunggulan suatu produk atau jasa. Pada dasarnya, kualitas pelayanan terbentuk dari adanya perbandingan antara ideal dan persepsi dari kinerja dimensi kualitas. Kualitas jasa sendiri semata-mata ditentukan oleh pelanggan sehingga kepuasan pelanggan dapat dicapai dengan memberikan kualitas yang baik. Dalam pelayanan kesehatan, kepuasan seorang pasien dapat tercipta melalui pelayanan yang paripurna dari para petugas pelayanan kesehatan kepada penerima pelayanan kesehatan. (5)

Seiring dengan perkembangan ilmu dan teknologi, pola pikir dan kesadaran masyarakat juga semakin meningkat dengan adanya pemahaman yang baik terhadap hak dan kewajibannya sebagai penerima pelayanan kesehatan. Sehingga, keadaan ini tentunya semakin menjadikan besarnya tuntutan bagi pihak rumah sakit untuk terus meningkatkan mutu pelayanan dan tanggung jawabnya dalam memberikan pelayanan kesehatan. Usaha peningkatan kualitas dan cakupan layanan kesehatan bagi masyarakat dapat dilakukan dengan salah satunya meningkatkan fasilitas kesehatan sebagai salah satu indikator dalam peningkatan kualitas pelayanan.

Tersedianya fasilitas kesehatan yang memadai dalam suatu pelayanan tentu akan memudahkan penerima pelayanan dalam menggunakan jasa pelayanan. Kelengkapan dan kemudahan penggunaan fasilitas kesehatan melalui sarana dan prasarana yang memadai akan menjadi suatu indikator penentu terhadap kepuasaan pasien dalam menerima pelayanan. Sehingga, memicu terjadinya perubahan pandangan masyarakat terhadap fasilitas kesehatan, dari sebuah kebutuhan menjadi sebuah pilihan bagi masyarakat. Perubahan pandangan ini akan memacu penyedia dan pengelola fasilitas kesehatan agar dapat memaksimalkan usahanya dalam memberikan pelayanan kesehatan yang baik, bermutu dan berkualitas. (1)

Terlepas dari hal tersebut, indikator lain untuk menilai dan meningkatkan kepuasan pasien juga dapat dilihat dari keberadaan petugas pelayanan di suatu rumah sakit. Sebagai sumber daya manusia, 
petugas pelayanan dituntut untuk memberikan pelayanan yang optimal dan berkualitas kepada pasien. Sehingga, dalam menjalankan perannya, dibutuhkan motivasi yang dapat memacu semangat kerja dari petugas. Dengan harapan, mereka dapat bekerja sama dalam menjalankan tugas dan perannya secara efektif dan terintegrasi dalam memberikan pelayanan kepada pasien. Hal ini kemudian, sangat berpengaruh terhadap produktivitas kerja petugas pelayanan. Dengan demikian, akan mempengaruhi kualitas dari mutu pelayanan kesehatan pada pasien yang menerima pelayanan di rumah sakit. (6)

RSUD Haji Makassar Provinsi Sulawesi Selatan merupakan salah satu rumah sakit milik Pemerintah Provinsi Sulawesi. RSUD Haji Makassar Provinsi Sulawesi Selatan merupakan salah satu rumah sakit rujukan yang ada di Makassar yang berusaha melakukan perbaikan dan peningkatan mutu pelayanan melalui suatu sistem manajemen mutu terintegrasi pada tahun 2010 dengan menerapkan ISO 9001:2008, ISO 14001:2004 dan OHSAS 18001:2007.(7) Pelayanan kesehatan yang bermutu merupakan salah satu kebutuhan dasar yang diperlukan setiap pelanggan atau konsumen. Tuntutan konsumen atas peningkatan kualitas produk dan jasa bertambah seiring terjadinya perubahan pandangan mengenai kualitas layanan. Dimana suatu produk yang berkualitas, tidak hanya merupakan produk dengan performance yang baik tetapi juga harus memenuhi kriteria kepuasan konsumen. (8)

Walaupun telah terstandar ISO, tetapi secara implementasi beberapa pasien masih belum terpuaskan akan harapan yang diinginkan, hal ini sesuai dengan penelitian terdahulu dimana pada hasil penelitiannya mengatakan bahwa responden merasa kurang puas terhadap kenyamanan di RSUD Haji Makassar. (9) Selain dari hasil penelitian diatas, hasil wawancara singkat yang telah peneliti lakukan sendiri di RSUD Haji Makassar dimana untuk fasilitas kesehatan yang dikeluhkan oleh beberapa pasien melalui hasil wawancara yaitu lahan parkir yang kurang memadai dan tidak ada penjagaan di parkiran serta kondisi toilet yang perlu diperbaiki.

Pengukuran kepuasan pelanggan merupakan elemen penting dalam menyediakan pelayanan yang lebih baik, efisien dan lebih efektif. Meskipun penelitian mengenai kepuasan pasien sudah sangat banyak, tetapi yang membedakan penelitian ini dibandingkan penelitian yang lainnya adalah pada kuisioner penelitian ini memasukkan instrument ISO pada pernyataannya. Maka berdasarkan keterangan diatas, penulis tertarik untuk melakukan penelitian mengenai pengaruh fasilitas kesehatan dan motivasi kerja terhadap kepuasan pasien melalui kualitas pelayanan pada unit rawat inap di RSUD Haji Makassar Provinsi Sulawesi Selatan.

\section{METODE}

Penelitian ini adalah penelitian kuantitatif dengan pendekatan Cross Sectional Study (potong lintang) yaitu rancangan penelitian dengan melakukan pengukuran atau pengamatan pada saat bersamaan atau sekali waktu, yang bertujuan mengetahui pengaruh fasilitas kesehatan dan motivasi kerja terhadap kepuasan pasien melalui kualitas pelayanan di RSUD Haji Makassar. Metode analisis data menggunakan analisis statistik 
VOL. 2, NO. 1, JANUARI-JUNI 2021

perhitungan dengan menggunakan program SPSS dengan menggunakan analisis jalur (path analysis).

Pengumpulan data dilakukan menggunakan kuesioner yang dibuat oleh peneliti dengan mengacu kerangka konsep dan variable - variabel yang akan diteliti kepada responden. Kuesioner dalam bentuk angket, yang diisi oleh pasien rawat inap di RSUD Haji Makassar.

Populasi dalam penelitian ini adalah pasien rawat inap kelas II, I, dan VIP di RSUD Haji Makassar. Sampel adalah bagian dari jumlah dan karakteristik yang dimiliki oleh populasi. Karena penelitian ini merupakan penelitian Cross Sectional Study maka besar sampel dapat dihitung dengan menggunakan rumus (Lemeshow, 1990) dengan jumlah sampel penelitian sebesar 68 pasien.

Pengumpulan data dilakukan sejak bulan Januari sampai Februari 2021 tentang Pengaruh Fasilitas Kesehatan dan Motivasi Kerja Terhadap Kepuasan Pasien Melalui Kualitas Pelayanan Pada Unit Rawat Inap di RSUD Haji Makassar Provinsi Sulawesi Selatan.

\section{HASIL}

Berdasarkan hasil penelitian mengenai pengaruh fasilitas kesehatan dan motivasi kerja terhadap kepuasan pasien melalui kualitas pelayanan pada unit rawat inap di RSUD Haji Makassar Provinsi Sulawesi Selatan diperoleh data :
Distribusi Responden Berdasarkan Karakteristik di Rumah Sakit

\begin{tabular}{|c|c|c|c|}
\hline \multicolumn{2}{|c|}{ Karakteristik. } & \multirow{3}{*}{$\begin{array}{c}\mathbf{n} \\
29 \\
39 \\
\end{array}$} & \multirow{3}{*}{$\begin{array}{c}\% \\
42.6 \\
57.4\end{array}$} \\
\hline & Laki-laki & & \\
\hline Jemis ketamua & Perempuan & & \\
\hline \multirow{6}{*}{ Usia } & $<20$ tahun & 3 & 4.4 \\
\hline & 20-29 tahun. & 14 & 20.6 \\
\hline & 30-39 tahun. & 14 & 20.6 \\
\hline & 40-49 tahun. & 18 & 26.5 \\
\hline & 50-59 tahuo. & 14 & 20.6 \\
\hline & $>=60$ tahun. & 5 & 7.4 \\
\hline \multirow{3}{*}{ Rawat inap } & VIP & 12 & 17.6 \\
\hline & Kelas 1 & 21 & 30.9 \\
\hline & Kelas 2 & 35 & 51.5 \\
\hline \multicolumn{2}{|c|}{ Jumlah } & 68 & 100.0 \\
\hline
\end{tabular}

Tabel di atas tentang karakteristik responden didapatkan bahwa responden berdasarkan kategori jenis kelamin diketahui bahwa jenis kelamin responden lebih didominasi oleh perempuan yaitu sebesar 39 orang $(57,4 \%)$ sedangkan yang berjenis kelamin laki-laki hanya 29 orang (42,6\%). Berdasarkan kelompok umur menjelaskan bahwa kelompok umur yang paling banyak adalah kelompok umur antara 40-49 tahun sebanyak 18 orang (26,5\%) disusul kelompok umur 20-39, dan 50-59 tahun sebanyak 14 orang $(20,6 \%)$ dan kelompok umur $>60$ tahun sebanyak 5 orang $(7,4 \%)$. Sedangkan kelompok umur yang paling sedikit adalah kelompok umur $<20$ tahun yang berjumlah 3 orang $(4,4 \%)$.

Berdasarkan kelas perawatan inap menunjukkan bahwa kelas perawatan yang paling banyak di dominasi pada perawatan kelas 2 sebanyak 35 pasien $(51,5 \%)$ dan yang terendah pada perawatan VIP sebanyak 12 responden $(17,6 \%)$.

\begin{tabular}{|c|c|c|c|c|c|}
\hline \multicolumn{6}{|c|}{ Hasil Uji Sub Struktur 1} \\
\hline \multirow[t]{2}{*}{ Model } & \multicolumn{2}{|c|}{$\begin{array}{l}\text { Unstandardized } \\
\text { Coesficientst. }\end{array}$} & \multirow{2}{*}{ 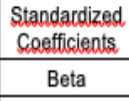 } & \multirow[t]{2}{*}{$\mathrm{T}$} & \multirow{2}{*}{ Sig. } \\
\hline & B & Std. Extors. & & & \\
\hline (Constant) & 7.816 & 4.146 & & 1.885 & .064 \\
\hline Fasilitas Kesehatan (X1) & .570 & 1144 & 481 & 5.010 & .000 \\
\hline Motivasi Kerja (X2) & .325 & .089 & .350 & 3.652 & .001 \\
\hline
\end{tabular}

Dari tabel diatas dapat dibuat persamaan jalur dari output tersebut yaitu: $\mathrm{Y} 1=7.816+0,481 \mathrm{X} 1+0,350 \mathrm{X} 2$ Artinya :

1. Konstanta

Nilai konstanta 7.816 bermakna apabila 
fasilitas kesehatan dan motivasi kerja bernilai tetap atau konstan atau bernilai nol maka kualitas pelayanan akan meningkat sebesar 7,816

2. Koefisien Variabel Fasilitas kesehatan Nilai fasilitas kesehatan (X1) sebesar 0,481 memberi makna bahwa apabila fasilitas kesehatan (X1) bertambah 1 poin, maka kualitas pelayanan kesehatan akan meningkat sebesar 0,481 .

3. Koefisien Variabel Motivasi Kerja

Nilai motivasi kerja (X2) sebesar 0,350 memberi makna bahwa apabila motivasi kerja (X2) bertambah 1 poin, maka kualitas pelayanan kesehatan akan meningkat sebesar 0,350 .

Hasil Analisis Alur Model 1

\begin{tabular}{|c|c|c|c|c|c|}
\hline & asil Uji & Sub Struktt & & & \\
\hline \multirow{2}{*}{ Model } & \multicolumn{2}{|c|}{$\begin{array}{l}\text { Unstandardized } \\
\text { Coeefficients }\end{array}$} & \multirow{2}{*}{\begin{tabular}{|c|}
$\begin{array}{c}\text { Standardized } \\
\text { Soesfficients }\end{array}$ \\
Beta \\
\end{tabular}} & \multirow{2}{*}{$\mathrm{T}$} & \multirow{2}{*}{ Sig. } \\
\hline & B & Std. Ercor. & & & \\
\hline (Constant) & 9.838 & 2.908 & & 3.382 & .001 \\
\hline Fasilitas Kesehatan (X1) & .496 & .080 & .604 & 6.213 & .000 \\
\hline Motivasi Kerja (X2) & .090 & .062 & .140 & 1.438 & 155 \\
\hline Kualitas Pelayanan (Y1) & .531 & .055 & .767 & 9.702 & .000 \\
\hline
\end{tabular}
dibuat persamaan jalur dari output tersebut yaitu: $\mathrm{Y} 2=9.838+0,604 \mathrm{X} 1+0,140 \mathrm{X} 2+$ 0,767Y1

Artinya :

\section{Konstanta}

Nilai kosntanta 9,838 bermakna apabila fasilitas kesehatan, motivasi kerja dan kualitas pelayanan bernilai tetap atau bernilai nol maka kepuasan pasien akan meningkat sebesar 9,838

2. Koefisien Variabel Fasilitas Kesehatan Nilai fasilitas kesehatan (X1) sebesar 0,604 memberi makna bahwa apabila fasilitas kesehatan (X1) bertambah 1 poin, maka kepuasan pasien akan meningkat sebesar 0,604.

3. Koefisien Variabel Motivasi Kerja

Nilai motivasi kerja (X2) sebesar 0,140 memberi makna bahwa apabila motivasi kerja (X2) bertambah 1 poin, maka kepuasan pasien akan meningkat sebesar 0,140 .

4. Koefisien Variabel Kualitas Pelayanan Nilai kulaitas pelayanan (Y1) sebesar 0,767 memberi makna bahwa apabila kualitas pelayanan (Y1) bertambah 1 poin, maka kepuasan pasien akan meningkat sebesar 0,767 .

pasien akan meningkat sebesar 0,140.

\begin{tabular}{ccc}
\multicolumn{3}{c}{ Pengaruh langsung dan tidak langsung berdasarkan analisis jalur } \\
\hline \multicolumn{1}{c}{ Yariabel } & Koefisien & Std Error \\
\hline $\mathrm{X} 1 \rightarrow \mathrm{Y} 1 \rightarrow \mathrm{Y} 2$ & $0,481 \times 0,767=0,368$ & - \\
$\mathrm{X} 2 \rightarrow \mathrm{Y} 1 \rightarrow \mathrm{Y} 2$ & $0,350 \times 0,767=0,268$ & - \\
$\mathrm{X} 1 \rightarrow \mathrm{Y} 2$ & 0.604 & 0,080 \\
$\mathrm{X} 2 \rightarrow \mathrm{Y} 2$ & 0,140 & 0,062 \\
$\mathrm{X} 1 \rightarrow \mathrm{Y} 1$ & 0,481 & 0,144 \\
$\mathrm{X} 2 \rightarrow \mathrm{Y} 1$ & 0.350 & 0,089 \\
$\mathrm{Y} 1 \rightarrow \mathrm{Y} 2$ & 0,767 & 0,055 \\
\hline
\end{tabular}

Nilai koefisien standarized pengaruh fasilitas kesehatan (X1) terhadap kualitas pelayanan (Y1) sebesar 0,481 dan pengaruh kualitas pelayanan (Y1) terhadap kepuasan pasien (Y2) sebesar 0,767 menunjukkan bahwa besarnya pengaruh langsung, sedangkan besarnya pengaruh tidak langsung dihitung dengan mengalikan koefisien $(\mathrm{X} 1 \rightarrow \mathrm{Y} 1) \mathrm{x}(\mathrm{Y} 1 \rightarrow \mathrm{Y} 2)$, yaitu $0,481 \times 0,767=0,368$. Pengaruh mediasi yang ditunjukkan bahwa perkalian koefisien (X1 $\rightarrow \mathrm{Y} 1) \mathrm{x}(\mathrm{Y} 1 \rightarrow \mathrm{Y} 2)$ sebesar 0,178 signifikan atau tidak diuji dengan sobel test sebagai berikut :

$\mathbf{S a b}=\sqrt{b^{2} S a^{2}+a^{2} S b^{2}+S a^{2} S b^{2}}$

Dimana :

a : Koefisien pengaruh Langsung $\mathrm{X} 1 \rightarrow \mathrm{Y} 1=0,481$

b : Koefisien pengaruh Langsung $\mathrm{Y} 1 \rightarrow \mathrm{Y} 2=0,767$

$\mathrm{Sa} \quad$ : Standar error dari koefisien $=0,114$

$\mathrm{Sb}:$ Standar error dari Koefisien $=0,089$

Hitung standar error dari koefisien pengaruh tidak langsung (indirect effect) dari $\mathrm{X} 1 \rightarrow \mathrm{Y} 1 \rightarrow \mathrm{Y} 2$ sebagai berikut $:$

$\mathbf{S a b}=\sqrt{b^{2} S a^{2}+a^{2} S b^{2}+S a^{2} S b^{2}}$ 


$$
\begin{aligned}
& =\sqrt{(0,767)^{2}(0,114)^{2}+(0,481)^{2}(0,089)^{2}+(0,114)^{2}(0,089)^{2}} \\
& =\sqrt{0,0070+0,00161+0,000084}=\sqrt{0,00869} \\
& =0,0932 \\
& \quad \frac{a x b}{\text { sab }}=\frac{0,481 x 0,767}{0,0932}=3,984
\end{aligned}
$$

Dari nilai $\mathrm{t}$ hitung sebesar 3,984 tersebut lebih besar dari t tabel 1,987, yang berarti bahwa parameter mediasi tersebut berpengaruh signifikan artinya bahwa fasilitas kesehatan berpengaruh postif terhadap kepuasan pasien melalui kualitas layanan kesehatan di RSUD Haji Kota Makassar.

Nilai koefisien standarized pengaruh motivasi kerja (X2) terhadap kualitas pelayanan (Y1) sebesar 0,350 dan pengaruh kualitas pelayanan (Y1) terhadap kepuasan pasien (Y2) sebesar 0,767 menunjukkan bahwa besarnya pengaruh langsung, sedangkan besarnya pengaruh tidak langsung dihitung dengan mengalikan koefisien $(\mathrm{X} 2 \rightarrow \mathrm{Y} 1) \mathrm{x}(\mathrm{Y} 1 \rightarrow \mathrm{Y} 2)$, yaitu $0,350 \times 0,767=0,268$. Pengaruh mediasi yang ditunjukkan bahwa perkalian koefisien (X2 $\rightarrow \mathrm{Y} 1) \mathrm{x}(\mathrm{Y} 1 \rightarrow \mathrm{Y} 2)$ sebesar 0,268 signifikan atau tidak diuji dengan sobel test sebagai berikut :

$\mathbf{S a b}=\sqrt{b^{2} S a^{2}+a^{2} S b^{2}+S a^{2} S b^{2}}$

Dimana :

a : Koefisien pengaruh Langsung $\mathrm{X} 2 \rightarrow \mathrm{Y} 1=0,350$

b : Koefisien pengaruh Langsung $\mathrm{Y} 2 \rightarrow \mathrm{Y} 1=0,767$

Sa $\quad$ Standar error dari koefisien $=0,114$ $\mathrm{Sb}$ : Standar error dari Koefisien = 0,089

Hitung standar error dari koefisien pengaruh tidak langsung (indirect effect) dari $\mathrm{X} 1 \rightarrow \mathrm{Y} 1 \rightarrow \mathrm{Y} 2$ sebagai berikut :

$\mathbf{S a b}=\sqrt{b^{2} S a^{2}+a^{2} S b^{2}+S a^{2} S b^{2}}$

$=\sqrt{(0,767)^{2}(0,114)^{2}+(0,350)^{2}(0,089)^{2}+(0,114)^{2}(0,089)^{2}}$ $=\sqrt{0,0070+0,00085+0,000084}$

$$
\begin{aligned}
= & \sqrt{0,00793} \\
= & 0,08906 \\
& \frac{a \times b}{s a b}=\frac{0,350 \times 0,767}{0,08906}=3,011
\end{aligned}
$$

Dari nilai $\mathrm{t}$ hitung sebesar 3,011

\begin{tabular}{|c|c|c|c|}
\hline \multicolumn{4}{|c|}{ Pengaruh langsung dan Pengaruh Tidak Langsung } \\
\hline Koefisien Jalur & $\begin{array}{c}\text { Standardized } \\
\text { Ceefficient }\end{array}$ & $T$ hitung & Ket \\
\hline$X_{1} \rightarrow Y_{1} \rightarrow Y_{2}$ & $0,481 \times 0,767=0,368$ & 3,984 & H1 diterima \\
\hline$X_{2} \rightarrow Y_{1} \rightarrow Y_{2}$ & $0,350 \times 0,767=0,268$ & 3,011 & H2 diterima \\
\hline $\mathrm{X} 1 \rightarrow \mathrm{Y}_{2}$ & 0,604 & 6.213 & H3 diterima \\
\hline$X 2 \rightarrow Y 2$ & 0,140 & 1.438 & $\mathrm{H} 4$ ditolalak \\
\hline$X 1 \rightarrow Y 1$ & 0,481 & 5.010 & H5 diterima \\
\hline$X_{2} \rightarrow Y_{1}$ & 0,350 & 3.652 & H6 diteriona \\
\hline$Y 1 \rightarrow Y 2$ & 0,767 & 9.702 & H7 diterima \\
\hline
\end{tabular}
tersebut lebih besar dari t tabel 1,987, yang berarti bahwa parameter mediasi tersebut berpengaruh signifikan artinya bahwa motivasi kerja berpengaruh postif terhadap kepuasan pasien melalui kualitas pelayanan kesehatan di RSUD Haji Kota Makassar.

Nilai $t$ hitung untuk variabel fasilitas kesehatan terhadap kepuasan pasien diperoleh sebesar 6.213 dengan nilai signifikansi 0,000 menunjukkan bahwa nilai $\mathrm{t}$ hitung lebih besar dari nilai t tabel 1,986 dan nilai signifikansinya lebih kecil dari 0,05 , dan nilai koefisien jalur menunjukkan tanda positif yaitu 0,604 maka dapat disimpulkan bahwa variabel fasilitas kesehatan berpengaruh positif dan signifikan terhadap kepuasan pasien di RSUD Haji Kota Makassar.

Nilai $t$ hitung untuk variabel motivasi kerja terhadap kepuasan pasien diperoleh sebesar 1.438 dengan nilai signifikansi 0,155 menunjukkan bahwa nilai $t$ hitung lebih kecil dari nilai $t$ tabel 1,986 dan nilai signifikansinya lebih besar dari 0,05, dan nilai koefisien jalur menunjukkan tanda positif yaitu 0,140 maka dapat disimpulkan bahwa variabel motivasi kerja tidak memiliki pengaruh yang signifikan terhadap kepuasan pasien di RSUD Haji Kota Makassar.

Nilai $t$ hitung untuk variabel fasilitas kesehatan terhadap kualitas 
pelayanan diperoleh sebesar 5.010 dengan nilai signifikansi 0,000 menunjukkan bahwa nilai $\mathrm{t}$ lebih besar dari nilai t tabel 1,986 dan nilai signifikansinya lebih kecil dari 0,05, dan nilai koefisien jalur menunjukkan tanda positif yaitu 0,481 maka dapat disimpulkan bahwa variabel fasilitas kesehatan berpengaruh positif dan signifikan terhadap kualitas pelayanan di RSUD Haji Kota Makassar.

Nilai $t$ hitung untuk variabel motivasi kerja terhadap kualitas pelayanan diperoleh sebesar 3.652 dengan nilai signifikansi 0,001, menunjukkan bahwa nilai $\mathrm{t}$ hitung lebih besar dari nilai $\mathrm{t}$ tabel 1,986 dan nilai signifikansinya lebih kecil dari 0,05 , dan nilai koefisien jalur menunjukkan tanda positif yaitu 0,350 maka dapat disimpulkan bahwa variabel motivasi kerja berpengaruh positif dan signifikan terhadap kualitas pelayanan di RSUD Haji Kota Makassar.

Nilai $t$ hitung untuk variabel kualitas pelayanan terhadap kepuasan pasien diperoleh sebesar 9.702 dengan nilai signifikansi 0,000 menunjukkan bahwa nilai $\mathrm{t}$ hitung lebih besar dari nilai t tabel 1,986 dan nilai signifikansinya lebih besar dari 0,05, dan nilai koefisien jalur menunjukkan tanda positif yaitu 0,767 maka dapat disimpulkan bahwa variabel kualitas pelayanan berpengaruh positif dan signifikan terhadap kepuasan pasien di RSUD Haji Kota Makassar.

Hasil pengujian struktur 1 dan struktur 2

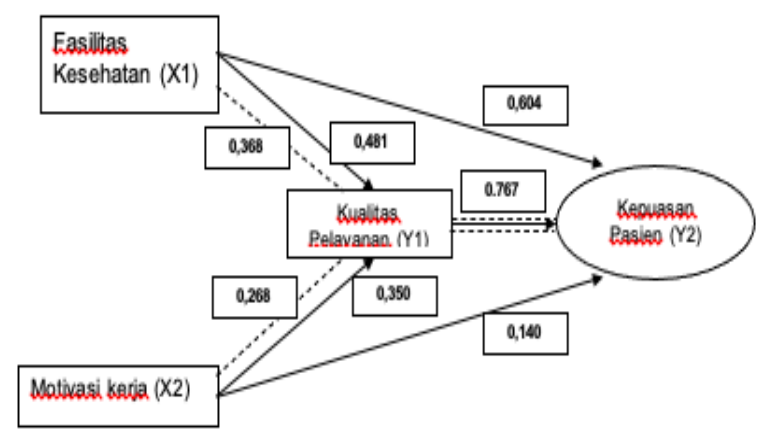

Berdasarkan gambar dapat dilihat pengaruh antara variabel baik secara langsung maupun tidak langsung.

\section{PEMBAHASAN}

1. Pengaruh fasilitas kesehatan terhadap kepuasan pasien melalui kualitas pelayanan pada unit rawat inap di RSUD Haji Makassar. Dari hasil analisis jalur menunjukkan bahwa pengaruh tidak langsung fasilitas kesehatan terhadap kepuasan melalui kualitas pelayanan diperoleh nilai koefisien variabel eksogen dan variabel intervening yaitu 0,618 yang memiliki angka > 0,306. Sehingga disimpulkan bahwa terdapat pengaruh positif dan signifikan fasilitas kesehatan terhadap kepuasan pasien melalui kualitas pelayanan di RSUD Haji Kota Makassar. Ini berarti bahwa jika fasilitas kesehatan dan kualitas pelayanan meningkat maka kepuasan pasien juga akan meningkat.

Hal ini juga sejalan dengan hasil penelitan (Yesinda \& Murnisari, 2018) menunjukkan Hasil uji f pada penelitian ini menunjukkan bahwa adanya pengaruh Fasilitas dan Kualitas Pelayanan terhadap kepuasan pasien. Hasil uji t pada penelitian ini menunjukkan adanya pengaruh secara parsial pengaruh Fasilitas dan Kualitas Pelayanan terhadap kepuasan pasien. Dilihat dari hasil analisis koefisien determinasi yang didapat nilai $\mathrm{R}$ Square sebesar 0,810 atau $81 \%$ variabel kepuasan pasien dapat dijelaskan oleh variabel Fasilitas dan Kualitas Pelayanan, sedangkan 19\% dijelaskan oleh variabelvariabel lain. 
Penelitian lain yang dilakukan oleh Sofyan, Pradhanawati, dan Nugraha (2013) berdasarkan penelitian dari hasil perhitungan menunjukkan tingkat keeratan hubungan antara fasilitas dan kualitas pelayanan terhadap kepuasan adalah kuat, karena nilai koefisien korelasi (r) adalah sebesar 0,775. Artinya, setiap perubahan fasilitas dan kualitas pelayanan dapat mempengaruhi kepuasan. Variabel fasilitas dan kualitas pelayanan secara simultan mempunyai pengaruh terhadap kepuasan konsumen. Fasilitas dan kualitas pelayanan secara bersama - sama berpengaruh positif dan signifikan terhadap kepuasan.

2. Pengaruh motivasi kerja terhadap kepuasan pasien melalui kualitas pelayanan pada unit rawat inap di RSUD Haji Makassar. Berdasarkan hasil analisis jalur menunjukkan pengaruh tidak langsung motivasi kerja terhadap kepuasan melalui kualitas pelayanan diperoleh nilai koefisien variabel eksogen dan variabel intervening yaitu 0,143 yang memiliki angka > 0,084. Sehingga disimpulkan bahwa terdapat pengaruh positif dan signifikan motivasi kerja terhadap kepuasan pasien melalui kualitas pelayanan di RSUD Haji Kota Makassar. Ini berarti bahwa jika motivasi kerja dan kualitas pelayanan meningkat maka kepuasan pasien juga akan meningkat.

Penelitian ini sejalan dengan dengan hasil penelitian yang dilakukan oleh Hadi dan Yonathan (2019) menyimpulkan bahwa motivasi berpengaruh positif dan signifikan terhadap kualitas pelayanan, motivasi berpengaruh positif dan tidak signifikan terhadap kepuasan pasien, kompetensi berpengaruh positif dan signifikan baik terhadap kualitas pelayanan maupun terhadap kepuasan pasien dan kualitas pelayanan berpengaruh positif dan signifikan terhadap kepuasan pasien (Hadi dan Yonathan, 2019).

Hal ini juga sesuai dengan hasil penelitian Rondiah (2017) menunjukkan bahwa motivasi kerja berpengaruh terhadap kualitas pelayanan RSUD Dr. H. Abdul Moeloek Provinsi Lampung. jika motivasi kerja bernilai 0 maka, kualitas pelayanan (X) 0,535 yang berarti bila motivasi kerja mengalami peningkatan $1 \%$ saja, maka kualitas pelayanan akan mengalami peningkatan sebesar $53,5 \%$ dan $\mathrm{t}$ tabel sebesar 1,98793 sedangkan t hitung sebesar 7,170 berdasarkan taraf signifikan $(0,000)<$ 0,05. Hal ini sangat mempengaruhi seseorang dalam bekerja dan berpengaruh besar terhadap motivasinya, sehingga menghasilkan kualitas pelayanan yang sangat baik di RSUD Dr. H. Abdul Moeloek Provinsi Lampung (Rondiah, 2017).

3. Pengaruh fasilitas kesehatan terhadap kepuasan pasien pada unit rawat inap di RSUD Haji Makassar. Berdasarkan hasil analisis, pengaruh langsung fasilitas kesehatan terhadap kepuasan pasien dapat dilihat dengan koefisien sebesar 0.306 dengan nilai signifikansi 0.000. Artinya nilai koefisien bernilai positif dan mempunyai signifikansi 0.000> 0.05. Koefisien tersebut menunjukkan bahwa fasilitas kesehatan berpengaruh signifikan terhadap kepuasan pasien. Ini berarti bahwa jika fasilitas kesehatan meningkat maka kepuasan pasien juga akan meningkat. Sehingga dapat disimpulkan bahwa 
variabel fasilitas kesehatan berpengaruh terhadap kepuasan pasien pada unit rawat inap di RSUD Haji Kota Makassar.

Hal ini sejalan dengan penelitian yang dilakukan oleh Badjamal, A Faigah (2014), berdasarkan hasil penelitian bahwa fasilitas kesehatan memiliki pengaruh yang signifikan terhadap kepuasan pasien pada rawat inap kelas III RSUD Undata Palu.

Dalam penelitian yang dilakukan

oleh Harfika dan Abdullah (2017) menunjukkan variabel fasilitas kesehatan berpengaruh terhadap kepuasan pasien pada Rumah Sakit Umum Teuku Peukan Kabupaten Aceh Barat Daya, implikasi penelitian ini menunjukkan bahwa fasilitas dapat diukur melalui manfaat atau dari apa yang telah disediakan oleh rumah rakit, apabila fasilitas yang disediakan oleh pihak rumah sakit memadai dan bisa memenuhi keinginan para pasien maka akan berdampak baik pula bagi perkembangan dan keberhasilan rumah sakit.

4. Pengaruh motivasi kerja terhadap kepuasan pasien pada unit rawat inap di RSUD Haji Makassar. Berdasarkan hasil analisis jalur menunjukan bahwa pengaruh langsung motivasi kerja terhadap kepuasan pasien dapat dilihat dengan koefisien sebesar -0.084 dengan nilai signifikansi 0.300. Artinya nilai koefisien bernilai negatif dan tidak signifikan 0.300> 0.05. Koefisien tersebut menunjukkan bahwa motivasi kerja tidak berpengaruh signifikan terhadap kepuasan pasien. Ini berarti bahwa jika motivasi kerja meningkat tidak berarti ikut menurunkan kepuasan pasien. Sehingga dapat disimpulkan bahwa variabel motivasi kerja tidak berpengaruh terhadap kepuasan pasien pada unit rawat inap di RSUD Haji Kota Makassar.

Dari hasil analisa peneliti mengapa tidak terdapat pengaruh pada motivasi kerja terhadap kepuasan pasien dikarenakan dasarnya kepuasan pasien berawal dari apa yang dirasakan langsung oleh pasien dalam hal ini tidak adanya pengaruh motivasi kerja terhadap kepuasan pasien karena hal tersebut tidak dapat dirasakan oleh pasien. Motivasi kerja dalam penelitian ini tidak berdampak secara langsung dan dirasakan oleh pasien sebab yang menjadi penilaian dalam motivasi kerja dalam penelitian ini berupa hubungan kerja antar sessama petugas kesehatan, promosi jabatan, pengembangan diri yang diamana semua pertanyaan tersebut hanya menilai kepuasan kerja pada petugas kesehatan, sehingga hal yang menyebabkan tidak adanya korelasi antara motivasi kerja terhadap kepuasan pasien.

Hal ini tidak sejalan dengan penelitian yang dilakukan oleh Silaban (2018) Hasil uji F menunjukkan bahwa motivasi kerja dan kepuasan kerja secara simultan berpengaruh signifikan terhadap komitmen perawat Rumah Sakit Ibu dan Anak Eria Bunda Pekanbaru. Hal ini berarti semakin optimal motivasi kerja dan kepuasan kerja yang diterima perawat maka semakin tinggi komitmen perawat terhadap rumah sakit dan secara parsial motivasi kerja berpengaruh signifikan terhadap komitmen perawat Rumah Sakit Ibu dan Anak Eria Bunda Pekanbaru (Silaban, 2018).

5. Pengaruh fasilitas kesehatan terhadap kualitas pelayanan pada unit rawat inap di RSUD Haji Makassar. Berdasarkan 
hasil analisis jalur menunjukkan bahwa pengaruh langsung fasilitas kesehatan terhadap kualitas pelayanan dapat dilihat dengan koefisien sebesar 0.504 dengan nilai signifikansi 0.000 . Artinya nilai koefisien bernilai positif dan mempunyai signifikansi $0.000>0.05$. Koefisien tersebut menunjukkan bahwa fasilitas kesehatan berpengaruh signifikan terhadap kualitas pelayanan. Ini berarti bahwa jika fasilitas kesehatan meningkat maka kualitas pelayanan juga akan meningkat. Sehingga dapat disimpulkan bahwa variabel fasilitas kesehatan berpengaruh positif dan signifikan terhadap kualitas pelayanan di RSUD Haji Kota Makassar.

Dari hasil analisa peneliti, fasilitas kesehatan berpengaruh positif dan signifikan terhadap kualitas pelayanan dikarenakan tersedianya fasilitas kesehatan yang baik di RSUD Haji maka hal ini menunjang kualitas pelayanan yang diberikan kepada pasien. Dengan adanya fasilitas kesehatan yang memadai dapat meningkatkan kualitas pelayanan yang diberikan petugas kesehatan di RSUD Haji. Berdasarkan sebaran jawaban responden, mayoritas responden mengungkapkan bahwa alat-alat kesehatan di RSUD Haji cukup lengkap, segala macam obat yang dibutuhkan oleh pasien tersedia, sehingga pasien tidak perlu lagi mencari diluar lingkungan rumah sakit.

Hal ini sesuai dengan dalam penelitian yang dilakukan oleh Yesinda dan Murnisari (2018) mengatakan bahwa semakin baiknya fasilitas kesehatan yang tersedia di Puskesmas Kademangan maka hal ini akan memengaruhi peningkatan kualitas pelayanan yang akan diberikan kepada pasien. (Yesinda \& Murnisari, 2018). Kemudian hasil penelitian yang dilakukan oleh Dewi (2019) menyatakan bahwa terdapat perbedaan kualitas pelayanan dalam fasilitas kesehatan di Klinik $\mathrm{X}$ dan $\mathrm{Y}$ setelah dilakukan uji analisa didapatkan hasil nilai Signifikan = 0,036 karena nilai Signifikan < 0,05 menyatakan adanya perbedaan antara Klinik X dan Klinik Y. Keberhasilan suatu jasa dalam memberikan pelayanan adalah melalui kualitas pelayanan dan fasilitas yang diberikan.

6. Pengaruh motivasi kerja terhadap kualitas pelayanan pada unit rawat inap di RSUD Haji Makassar. Berdasarkan hasil analisis jalur menunjukkan bahwa pengaruh langsung motivasi kerja terhadap kualitas pelayanan dapat dilihat dengan koefisien sebesar 0.367 dengan nilai signifikansi 0.000. Artinya nilai koefisien bernilai positif dan mempunyai signifikansi $0.000>0.05$. Koefisien tersebut menunjukkan bahwa motivasi kerja berpengaruh signifikan terhadap kualitas pelayanan. Ini berarti bahwa jika motvasi kerja meningkat maka kualitas pelayanan juga akan meningkat. Sehingga dapat disimpulkan bahwa variabel motivasi kerja berpengaruh positif dan signifikan terhadap kualitas pelayanan di RSUD Haji Kota Makassar.

Dari hasil analisa peneliti, hal ini dikarenakan bahwa untuk meningkatkan kualitas pelayanan, dibutuhkan motivasi dari pemberi layanan. Kualitas dalam pemberian pelayanan merupakan salah satu tuntutan baik dari pasien dan manajemen RSUD Haji Makassar hal ini yang menjadi dasar bahwa salah satu cara untuk untuk 
memberikan layanan yang berkualitas diperlukan motivasi kerja yang positif dimana RSUD Haji berupaya memberikan hal-hal yang bersifat positif bagi petugas salah satunya memberikan tunjangan yang cukup, menciptakan suasana kerja yang harmonis, memberikan reward agar petugas kesehatan di RSUD Haji Makassar dapat bekerja sepenuh hati, penuh tanggung jawab agar tercipta pelayanan kesehatan yang berkualitas yang dapat diterima dengan baik oleh pasien.

Hasil ini sesuai dengan penelitian yang dilakukan oleh Talle (2019) menunjukkan bahwa peningkatan motivasi dapat meningkatkan kualitas pelayanan di ULP Kabupaten Mamuju Utara. Peningkatan tersebut disebabkan oleh adanya hubungan positif di antara variabel, yang dapat dikatakan bahwa peningkatan kualitas pelayanan ULP dapat ditentukan oleh motivasi. Jadi berdasarkan hasil tersebut, maka keberadaan motivasi dalam penelitian ini sangat penting dalam mempengaruhi perubahan dari kualitas pelayanan yang dilakukan ULP dengan besar pengaruh tersebut adalah 63,3\%. Hal ini mengindikasikan bahwa motivasi memegang peranan penting dalam meningkatkan kualitas pelayanan yang dilakukan ULP Kabupaten Mamuju Utara kepada para rekanan (Talle, 2019).

7. Pengaruh kualitas pelayanan terhadap kepuasan pasien pada unit rawat inap di RSUD Haji Makassar. Berdasarkan hasil analisis jalur menunjukkan bahwa pengaruh langsung kualitas pelayanan terhadap kepuasan pasien dapat dilihat dengan koefisien sebesar 0.619 dengan nilai signifikansi 0.000 . Artinya nilai koefisien bernilai positif dan mempunyai signifikansi $0.000>0.05$. Koefisien tersebut menunjukkan bahwa kualitas pelayanan berpengaruh signifikan terhadap kepuasan pasien. Ini berarti bahwa jika kualitas pelayanan meningkat maka kepuasan pasien juga akan meningkat. Sehingga dapat disimpulkan bahwa variabel kualitas pelayanan berpengaruh positif dan signifikan terhadap kepuasan pasien di RSUD Haji Kota Makassar.

Berdasarkan hasil penelitian tersebut, RSUD Haji Makassar telah menunjukkan akan peningkatan mutu pelayanannya selain itu diketahui pula bahwa RSUD Haji Makassar telah terstandar oleh sistem manajemen mutu terintegrasi pada tahun 2010 dengan menerapkan ISO 9001:2008, ISO 14001:2004 dan OHSAS 18001:2007. Sehingga untuk kualitas pelayanan yang diberikan kepada pasien telah terstandar.

Pelayanan yang berkualitas berperan penting dalam membentuk kepuasan pasien di RSUD Haji Makassar, selain itu juga erat kaitannya dalam menciptakan keuntungan bagi rumah sakit. Semakin berkualitas pelayanan yang diberikan oleh petugas kesehatan maka kepuasan yang dirasakan oleh pasien akan semakin tinggi.

Artinya bahwa makin baik kualitas layanan yang dirasakan oleh pasien menyebabkan pasien makin puas sehingga mereka memiliki niat yang makin kuat untuk kembali menggunakan jasa tersebut di kemudian hari.

Hal ini sesuai dengan hasil penelitian oleh Engkus (2019), membuktikan bahwa terdapat hubungan pengaruh kualitas pelayanan yang kuat 
terhadap kepuasan pasien di Puskesmas Cibitung Kabupaten Sukabumi, yaitu dengan koefisien regresi kualitas pelayanan bernilai positif sebesar 0,456 , artinya setiap kualitas pelayanan bernilai 1, maka kepuasan pasien sebesar 0,456. Dalam uji t, diperoleh nilai $\mathrm{t}$ hitung $>\mathrm{t}$ tabel $(11,955>$ 1,988), artinya bahwa secara parsial terdapat pengaruh yang signifikan antara kualitas pelayanan terhadap kepuasan pasien di Puskesmas Cibitung Kabupaten Sukabumi. Berdasarkan hasil analisis korelasi diperoleh $\mathrm{R}$ sebesar 0,772, yang menunjukkan bahwa terdapat hubungan yang kuat antara kualitas pelayanan dengan kepuasan pasien (Engkus, 2019).

Adapun penelitian yang dilakukan oleh Sari (2020), menyatakan bahwa kualitas pelayanan mempengaruhi kepuasan pasien di Puskesmas Urug Kota Tasikmalaya sebesar 0,732. Ini artinya kualitas pelayanan berpengaruh sebesar $73,2 \%$ terhadap kepuasan pasien di Puskesmas Urug Kota Tasikmalaya dipengaruhi oleh dimensi-dimensi kualitas pelayanan secara simultan, dan sisanya yaitu $26,8 \%$ dipengaruhi variabel lain yang tidak diteliti (Sari, 2020).

\section{KESIMPULAN}

Berdasarkan hasil penelitian dan pembahasan maka diperoleh kesimpulan bahwa terdapat pengaruh fasilitas kesehatan dan motivasi kerja terhadap kepuasan pasien melalui kualitas pelayanan di RSUD Haji Makassar. Sehingga disarankan kepada pihak rumah sakit untuk mempertahankan kualitas pelayanannya.

\section{SARAN}

Diharapkan kepada pihak pihak RSUD Haji untuk tetap mempertahankan mutu layanan, sedangkan untuk motivasi pegawai diharapkan pimpinan dapat memberikan reward bagi pegawai yang teladan sehingga dapat memotivasi diri sendiri dan pegawai lainnya. Dan diharapkan kepada peneliti selanjutnya untuk dapat mengadakan penelitian yang mendalam dengan cakupan layanan yang lebih luas mengenai kualitas pelayanan, motivasi dan fasilitas kesehatan terhadap kepuasan pasien, berdasarkan fenomena yang ada guna menghasilkan penelitian baru dengan hasil yang lebih baik serta lebih berguna bagi masyarakat.

\section{DAFTAR PUSTAKA}

1. Ridwan, I., \& Saftarina, F. (2015). Pelayanan Fasilitas Kesehatan: Faktor Kepuasan Dan Loyalitas Pasien. Majority, 9. 4(9), 20-26. http://juke.kedokteran.unila.ac.id/index. php/majority/article/view/1403

2. Mongkaren, S. (2013). Fasilitas Dan Kualitas Pelayanan Pengaruhnya Terhadap Kepuasan Penguna Jasa Rumah Sakit Advent Manado. Jurnal Riset Ekonomi, Manajemen, Bisnis Dan Akuntansi, 1(4), 493-503.

3. Kemenkes RI. (2008). Permenkes Ri No 828 Tahun 2008 Tentang Petunjuk Teknis Standar Pelayanan Minimal. Jakarta: Depkes RI.

4. Tjiptono, Fandy \& Gregorius, C.(2006). Service Quality $\&$ Satisfaction.Yogyakarta: Andi Offset

5. Agung M, Muzakir, Gunawan. (2016). Pengaruh Kualitas Pelayanan Keperawatan, Fasilitas Dan Minat Terhadap Kepuasan Pasien Di Ruang 
Rawat Inap RSU Wisata UIT Makassar. Jurnal Mirai Management. Vol.1, No. 2. $30-44$

6. Sumartyawati N, Ardani M, Dharmana E. (2017). Hubungan Motivasi Dengan Kepuasan Kerja Perawat Di Ruang Rawat Inap RSJ Provinsi NTB. Prima, 3(1), 8-14.

7. Profil RSUD Haji Makassar Provinsi Sulawesi Selatan Tahun 2019 http://rsudhaji.sulselprov.go.id.pdf

8. Irawati S. (2013). Tesis Analisis Pengaruh Sistem Manajemen Mutu ISO Terhadap Kinerja Karyawan Melalui Budaya Patient Safety Di RSUD Haji Provinsi Sulawesi Selatan Tahun 2012. Magister Kesehatan Masyarakat, Universitas Hasanuddin. Makassar

9. Datuan, Nirmayasri; Darmawansyah; Daud, Anwar. (2018). Pengaruh Kualitas Pelayanan Kesehatan Terhadap Kepuasan Pasien Peserta BPJS Di Rumah Sakit Umum Daerah Haji Makassar. Jurnal Kesehatan Masyarakat Maritim, 3(1), 291-300

10. Badjamal, A Faigah. (2014). Pengaruh Kompetensi Dan Fasilitas Terhadap Kepuasan Pasien Rawat Inap Kelas 3 Pada RSUD Palu. e-Jurnal Katologis Vol 2(7)

11. Dewi, N. L., \& Ni Luh Gede Ari Natalia Yudha, M. A. (2019). Analisis Kualitas Pelayanan Dalam Fasilitas Kesehatan Tingkat Pertama Oleh Ibu Hamil Peserta Jaminan Kesehatan Nasional Di Dua Klinik Kecamatan Denpasar Selatan. Jurnal Kesehatan Terpadu, 3(2) : 82 - 88.

12. Engkus. (2019). Pengaruh Kualitas Pelayanan Terhadap Kepuasan Pasien Di Puskesmas Cibitung Kabupaten
Sukabumi. Jurnal Governansi, Volume 5 Nomor 2.

13. Hadi, H. H., \& Yonathan Pongtuluran, I. G. (2019). Pengaruh Motivasi Dan Kompetensi Perawat Terhadap Kualitas Pelayanan Dan Kepuasan Pasien. Jurnal Ilmu Manajemen Mulawarman, Vol. 4 No.1.

14. Harfika, J., \& Dan. (2017). Pengaruh Kualitas Pelayanan Dan Fasilitas Terhadap Kepuasan Pasien Pada Rumah Sakit Umum Kabupaten Aceh Barat Daya. J Balance, XIV(1), 44-56.

15. Karyanto, J. A. (2015). Analisis Faktor yang Mempengaruhi Kepuasan Pasien Rawat Inap Peserta BPJS non PBI di Puskesmas Kabupaten donggala. Universitas Hasanuddin.

16. Peraturan Kementerian Kesehatan Republik Indonesia Tahun tentang Standar Pelayanan Minimal. 2016

17. Rangkuti, F. (2006). Measuring Customer Satisfaction. Jakarta: Gramedia Pustaka Utama.

18. Rondiah, S. (2017). Pengaruh Impelementasi Motivasi Kerja Terhadap Kualitas Pelayanan Persepektif Etika Kerja Islam (Studi Pada Rsud Dr. H. Abdul Moeloek Provinsi Lampung). Skripsi Fakultas Ekonomi Dan Bisnis Islam Universitas Islam Negeri Raden Intan Lampung.

19. Rusmiati; Rasyidin Abdullah; Hasmin Tamsah. (2018). Pengaruh Kualitas Pelayanan, Fasilitas dan Citra Terhadap Kepuasan Pasien di Puskesmas Solo Kabupaten Wajo. Jurnal Stie Amkop, 113.

20. Sari, I. K. (2020). Pengaruh Kualitas Pelayanan Terhadap Kepuasan Pasien Di Puskesmas Urug Kecamatan Kawalu 
Kota Tasikmalaya. Dinamika : Jurnal Ilmiah Ilmu Administrasi Negara, Volume 7 Nomor 1.

21. Silaban, E. J. (2018). Pengaruh Motivasi Kerja Dan Kepuasan Kerja Terhadap Komitmen Perawat (Kasus Rumah Sakit Ibu Dan Anak Eria Bunda Pekanbaru). Jom Fisip, V01. 5(1).

22. Sofyan I L, Pradhanawati A, Nugraha S Hari. (2013). Pengaruh Fasilitas dan Kualitas Pelayanan Terhadap Loyalitas, Melalui Kepuasan Konsumen Sebagai Variabel Intervening Pada Star Clean
Car Wash Semarang. Diponegoro Journal of Social and Politic. 1-12

23. Talle, A. (2019). Pengaruh Motivasi Terhadap Kualitas Pelayanan Pada Unit Layanan Pengadaan Kabupaten Mamuju Utara . E Jurnal Katalogis, Vol.4(4);201-210.

24. Yesinda, I. S., \& Murnisari, R. (2018). Pengaruh Fasilitas Dan Kualitas Pelayanan Terhadap Kepuasan Pasien Jasa Rawat Jalan Pada Puskesmas Kademangan Kabupaten Blitar. Jurnal Penelitian Manajemen Terapan, Vol.3(2);206-214. 